\title{
Trophic interaction and diversity of cavity-nesting bees and wasps (Hymenoptera: Aculeata) in Atlantic forest fragments and in adjacent matrices
}

\author{
Michele Cristina Nether, Jessica Dudek, Maria Luisa Tunes BuschinI \\ Programa de Pós Graduação em Biologia Evolutiva da Universidade Estadual do Centro-Oeste, Rua Simeão Camargo \\ Varela de Sá 03, Vila Carli, Guarapuava, PR 85040-080, Brazil
}

Received 13 March 2018 - Revised 12 November 2018 - Accepted 7 December 2018

\begin{abstract}
The Brazilian Atlantic Forest is on the list of the 35 world hotspots with priority for conservation because it is home to one of the most diversified and threatened fauna and flora in the world. We studied the diversity and the food webs of cavity-nesting bees and wasps and their natural enemies (parasitoids and kleptoparasites) in three Atlantic forest fragments and adjacent matrices. Although the species composition in the forest fragments was different from the adjacent matrices, the alpha diversity stayed constant. Since the structure of the interaction networks between these species has not been altered with habitat simplification, we conclude that these relations are not shaped by recent environmental changes, but by phylogenetic relations established at a more remote time.
\end{abstract}

assembly / biodiversity / food web / insects / network / trap nests

\section{INTRODUCTION}

The human exploitation of natural systems has led the fragmentation of several biomes, altering their configuration, increasing the edge effect, and, consequently, provoking the loss of adequate habitats for focal species, which are those essential to the maintenance and stability of ecosystems (Smith et al. 2009).

The changes in the remaining fragments and where the vegetation cover was removed or replaced by crop systems cause habitat simplification (Stein et al. 2014), and produce negative effects on biodiversity, by diminishing the abundance and species richness, or even by provoking the substitution of their species

Corresponding author: M. Buschini, isatunes@yahoo.com.br

Manuscript editor: James Nieh
(Schüepp et al. 2011). This is because biodiversity may be related to the environment structural complexity (Ebeling et al. 2012). Therefore, the greater the structural complexity of a habitat, the greater the diversity and availability of its resources, of its available niches, and, consequently, the greater will be its biodiversity (MacArthur and MacArthur 1961).

Some studies have been carried out to try to understand how hymenopterans are affected by different habitat changes resulting from human intervention, like fragmentation and replacement of natural vegetation cover (Steffan-Dewenter 2003). The susceptibility of these insects to such modifications is due to the specialization they present towards food resources, nesting sites, and nest-building materials (Steffan-Dewenter 2002), which make them a suitable group for studies that aim to verify the consequences of fragmentation and substitution of vegetation cover on biodiversity (Klein et al. 2006).

Furthermore, due to their small size, high species richness, and trophic complexity, these 
hymenopterans are a suitable system to study complex multitrophic interactions (Tylianakis et al. 2007). However, little is known about the structure of interactions between them and their natural enemies, and how this might affect associated ecological processes (Tylianakis et al. 2007). The relevance of those studies is in the important ecological processes performed by these insects, given that bees act as effective pollinators of plants both native and cultivated, and wasps are predators of different species of spiders, cockroaches, grasshoppers, and caterpillars for the provisioning of their nests (Luck et al. 2003).

One important approach to describing the structure and understanding the dynamics of interspecific interactions within ecological communities is the study of interaction networks (Ings et al. 2009). Furthermore, these studies provide a natural tool with which to examine the effects of biodiversity on ecosystem functioning and stability (Tylianakis et al. 2007, 2010).

The topology of ecological networks has received attention from ecologists and evolutionary biologists because the position of species within these networks could affect their vulnerability to disturbance (Montoya et al. 2006) and their evolutionary dynamics (Bascompte et al. 2006). Quantification of the strength of interactions between species is essential for understanding how ecological communities are organized and how they respond to human exploitation (Bascompte et al. 2005).

Understanding the mechanisms maintaining biodiversity requires quantitative data on hostparasitoid food webs, especially from the tropics where these food webs are poorly known (Godfray et al. 1999). The ecosystem functioning seems to be the net result of interactions within and among trophic levels (Wilby and Orwin 2013) and some studies suggest that the relationship between diversity and ecosystem function is more complex and variable at higher trophic levels (Hooper et al. 2005).

Since several studies have largely focused on biodiversity losses within a single trophic level (Hillebrand and Matthiessen 2009), here, we examined the diversity and the food webs of cavitynesting bees and wasps and their natural enemies (parasitoids and kleptoparasites) in three Atlantic forest fragments and adjacent matrices. Therefore, the aim of this study was to test the following hypotheses: (1) The community structure in cavity-nesting bees and wasps and their natural enemies change with the removal of forest; (2) The food web structure change with habitat modification; (3) In deforested matrices, there is a higher ratio of natural enemies to host species and increased parasitism rates.

\section{MATERIALS AND METHODS}

\subsection{Study area}

The study was performed in three fragments of Mixed Ombrophilous Forest (Araucaria forest fragments) and three anthropized areas adjacent to the forest fragments called "adjacent matrices" in this study, where the vegetation cover of the forest was removed.

Araucaria forest fragments belong to permanent preservation areas, ranging from 43 to $200 \mathrm{ha}$, and their adjacent matrices from 6.8 to 111 ha. Two of the fragments are located in the Guarapuava municipality, Parana' state $\left(25^{\circ} 21^{\prime}\right.$ 4.28" S and $51^{\circ} 28^{\prime} 4.94^{\prime \prime} \mathrm{O}$, and $25^{\circ} 21^{\prime} 4.28^{\prime \prime} \mathrm{S}$ and $51^{\circ} 28^{\prime} 4.94^{\prime \prime} \mathrm{O}$ ), $10 \mathrm{~km}$ away from each other. The third fragment is located in the Municipality of Turvo, Parana'state $\left(25^{\circ} 01^{\prime} 51.34^{\prime \prime} \mathrm{S}\right.$ and $\left.51^{\circ} 31^{\prime} 54.02^{\prime \prime} \mathrm{O}\right), 25 \mathrm{~km}$ from the other fragments (Figure 1).

According to Köppen climate classification, the climate is $\mathrm{Cfb}$-oceanic climate, mesothermic, with average temperatures in the coldest month below $18{ }^{\circ} \mathrm{C}$ and in the warmest month, below $22^{\circ} \mathrm{C}$, without a defined dry season (IAPAR 2013). Frosts are frequent in these locations, where it has even snowed on occasion.

\subsection{Samplings}

Trap nests made of wooden blocks drilled longitudinally to a depth of $80 \mathrm{~mm}$ were used to sample the bees and wasps. The cavity diameters of these traps were $0.5,0.7,1.0$, and $1.3 \mathrm{~cm}$. Each nest was sawn along its length and halved (held together by tape). These nests were grouped in a larger block containing 16 trap nests and arranged randomly with four nests of each diameter. Each 


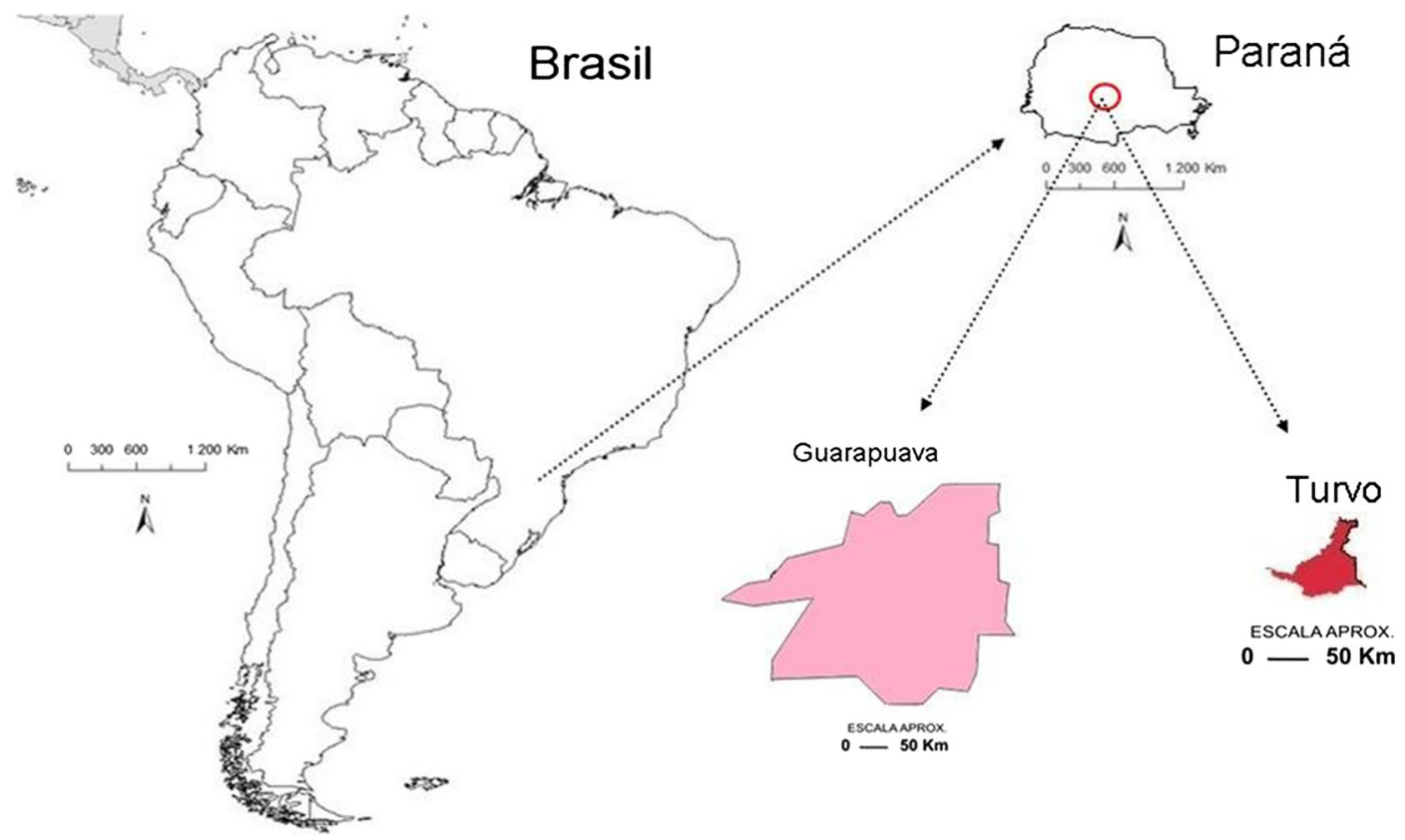

Figure 1 Location of the study areas.

block was fixed in a 1.5-m-high timber pile covered by tile roofs. Each area received six blocks, distributed randomly with a 50-m distance between the blocks, totaling 576 available trap nests in the field.

Using an otoscope, the trap nests were inspected every 15 days from September 2012 to June 2013. Each occupied and finished nest was removed and substituted by an empty one with the same diameter. The occupied nests were kept in the laboratory until the emergence of the adults. After emergence, the individuals were killed, pinned, labeled, and identified to species and morphospecies levels and were deposited at the entomological collection of the Biology and Ecology Laboratory of Bees and Wasps, Universidade Estadual do Centro-Oeste, Guarapuava (PR), Brazil.

\subsection{Diversity and composition of bee and wasp species}

As most studies of wasps and bees that nest in pre-existing cavities in Brazil (Buschini 2006; Buschini and Woiski 2008; Iantas et al. 2017; Flores et al. 2018) represent the abundance of species by the number of nests founded by them, in this study, abundance is being represented by the number of nests built for each species in each habitat to calculate alpha and beta diversities, frequency of occurrence, and species dominance.

In order to estimate the probable number of species present in each area, species richness estimators Chaol (Chao 1987), first order Jackknife (Palmer 1991), and Bootstrap (Smith and Van Belle 1984) were used. Chao is based on abundance and uses the relation between the number of singletons and doubletons (Colwell et al. 2004). All the tests were performed using $\mathrm{R}$ software version 3.0.2.

Alpha diversity of the bee and wasp communities in each study area was calculated using Shannon-Wiener diversity $H^{\prime}$ (measures community diversity), Margalef richness Dmg (degree of species richness) and Pielou evenness $J$ ' (indicates if different species possess similar or divergent abundances). The Student's $t$ test was carried out with the aim of testing the null hypothesis that there were no significant differences between the mean values of the indices obtained for the different areas. Jaccard's index, which ranges from 0 to 1, was used to measure Beta diversity, that is, the 
similarity among the habitats in relation to the presence-absence of species. The greatest similarities are found when the value of this index is close to 1 (Ludwig and Reynolds 1988). The analyses were performed using $\mathrm{R}$ software version 3.0.2, package Vegan (Oksanen et al. 2013).

Species frequency of occurrence (FO) and species dominance $(D)$ were calculated according to Palma (1975): FO = (number of samplings with species $i /$ number of samplings) $\times 100$. If $\mathrm{FO} \geq 50 \%$, the species is termed a primary species; if $50 \% \geq \mathrm{FO} \geq 25 \%$, the species is termed a secondary species; if $25 \% \geq \mathrm{FO}$, the species is termed an incidental species. $D=$ (Abundance of species $i /$ total abundance) $\times 100$. If $D>5 \%$, the species is termed a dominant species; if $2.5 \%<D<5 \%$, the species is termed an accessory species; if $D<2.5 \%$, the species is termed an incidental species. Palma (1975) reported that these indices could be used together to group the species into three categories: common species, intermediate species, and rare species.

\subsection{Interaction networks}

Connectance is the proportion of observed interactions in the network, in relation to the possible amount of interactions, and is given by $C=L /$ $(I \times J)$, where $L$ is the number of recorded interactions, $I$ and $J$ are, respectively, the number of host and natural enemy species present in the network. It permits us to understand and relate as the degree of generalization or redundancy in a system, with consequences for community stability (Blüthgen et al. 2008), values close to 1 reveal networks with all species are completely generalized and interactions are unlimited.

Another metric, also used to verify network specialization, was the H2' specialization index and selectiveness between all species in the bipartite web (Blüthgen et al. 2006), a bidimensional measure derived from the Shannon index, which evaluates the niche overlap among species, which ranges from 0 (extreme generalization) to 1 (extreme specialization) (Blüthgen et al. 2006).

The nestedness shows the tendency for the specialists (species with few links) interact with generalists (species with many links). It was tested using the NODF (Nestedness metric based on Overlap and Decreasing Fill; Almeida-Neto et al. 2008), using null templates which measure the network fulling and sorting degree.

The secondary extinction curve, proposed by Memmott et al. (2004), is the proportion of species on a superior trophic level that persists in the networks when a species from a lower trophic level becomes extinct. The method used to test the secondary extinctions of natural enemy as a function of the extinction of their hosts was random extinctions. One thousand randomizations were performed for these simulations, which allow the stability of networks to be gauged, through the number of secondary extinctions, and also allow network robustness to be calculated.

The calculation of network robustness, as proposed by Burgos et al. (2007), is defined as the area of extinction curve proposed by Memmott et al. (2004). The values obtained from this measurement range from 0 to 1 : the closer to 1 , the greater the robustness to secondary extinctions, making the network more stable.

The link evenness is a measure analogous to Shannon diversity, but with trophic interactions as the base unit instead of species (Bersier et al. 2002); Tylianakis et al. (2007). Link density is given by the average number of links between host species and their natural enemy, weighted the contribution of each link, reflecting the energy flow distribution degree between host and parasite. Vulnerability is given by the average number of natural enemy species per host, generalism by the average number of host species per natural enemy, which shows the dependency of natural enemy species by their host, and parasitism rate by the proportion of parasitized hosts.

To calculate these quantitative metrics we considered all the cells that were provisioned, that is, both those that were parasitized and those from where the hosts emerged (Tylianakis et al. 2007).

All measures of diversity and of interaction networks were calculated for each adjacent matrix and forest fragment, and afterwards, the Student's $t$ test was carried out to ascertain if there were significant differences between the averages for both kinds of areas. 
All metrics were calculated using package $\mathrm{Bi}$ partite 1.06 (Dormann et al. 2008) in R software version 3.0.2.

\section{RESULTS}

\subsection{Diversity and composition of bee and wasp species}

A total of 552 nests were collected, with $46 \%$ of them being founded in forest fragments and $54 \%$ in the adjacent matrices. The richness of wasps and bees was greater in adjacent matrices than in forest fragments, the values obtained for richness estimators indicate that the number of species collected in these areas is very close to the richness of each environment (Table I). There was no significant difference between indices of species richness $(t=$ $0.0887, p=0.7807)$, diversity $(t=1.225, p=$ $0.331)$, and evenness $(t=2.478, p=0.191)$ of adjacent matrices and forest fragments (Table I), and the similarity between adjacent matrices and forest fragments, regarding the species they share, was low $(J=0.17)$.

Only three species were common to adjacent matrices and forest fragments: Trypoxylon agamemnon, classified as common in the forest fragments and rare in the adjacent matrices, Trypoxylon lactitarse, classified as intermediary in the forest fragments and common in the adjacent matrices, and Auplopus rufipes, classified as intermediary in both areas.

The species that founded more nests in the forest fragments were Ancistrocerus flavomarginatus (54.3\% of nests) and Trypoxylon agamemnon (31\% of nests), and the other six species were considered as either intermediary or rare. In the adjacent matrices, the common species were Centris tarsata (21.96\% of nests), Trypoxylon opacum (37.5\% of nests), and Trypoxylon lactitarse ( $7.3 \%$ of nests). Five species were classified as intermediary and four as rare (Table II).

\subsection{Interaction networks}

In the forest fragments, 54 interactions were recorded between the natural enemy (parasitoids and kleptoparasites) and the 780 cells founded by hosts (wasps and bees). In contrast, in the adjacent matrices, 105 interactions were recorded between natural enemy and the 996 cells founded by hosts. Out of the eight host species that founded nests in the forest fragments, six had their nests parasitized by nine natural enemy species. In the adjacent matrices, out of 12 host species that founded nests, eight had their cells parasitized by 13 natural enemy species (Table III).

There was no significant difference between the metrics of the forest fragment and adjacent matrices networks (Table IV). The curves simulating network tolerance to the loss of natural enemy species as a function of the extinction random of hosts (Figure 2) indicated robustness values not significantly different between areas. Also, other methods of modeling extinction remove species in order of abundance and link density; however, no significant difference was found among areas. The bipartite graphs clearly show that there were no common natural enemies for more than one host, making the hosts disconnected from each other, indicating each host to be an insulated module in the networks (Figure 3).

\section{DISCUSSION}

Taken as a whole, our results did not support the hypotheses that the structure of these insect communities changes with forest removal. Although the species composition in the forest fragments was different from the deforested matrices, the alpha diversity did not statistically differ. Regarding this guild of wasps and bees, Ricketts (2004) and Tylianakis et al. (2006) did not find significant differences in alpha diversity either, when comparing forest and anthropized areas. Caution is required when analyzing such measures, for such a lack of significant difference between the indexes does not mean that local diversity would not be affected by the removal of forests. Much information about the structure of such communities can be lost when too much attention is given only to measures of alpha diversity (Tylianakis et al. 2007). 
Table I. Richness estimators for cavity-nesting wasps and bees in adjacent matrices and forest fragments

\begin{tabular}{lll}
\hline & Adjacent matrices & Forest fragments \\
\hline Number of species collected & 12 & 8 \\
Chao 1 & $14( \pm 3.74)$ & $10( \pm 3.74)$ \\
Jackknife 1 & $13.94( \pm 1.92)$ & $9.90( \pm 1.34)$ \\
Bootstrap & $12.88( \pm 1.03)$ & $8.85( \pm 0.75)$ \\
Shannon-wiener & 1.47 & 1.07 \\
Pielou & 0.59 & 0.51 \\
Margaleff & 1.61 & 0.89 \\
\hline
\end{tabular}

Considering the structure of their food web, measures of networks in forest fragments and their adjacent matrices did not present significant differences, which made us reject our second hypothesis. According to Morris et al. (2014), this could be more related to repetitive patterns found in host-parasitoid networks, than to the influence of the environment where these insects are found. In the adjacent matrices, there was removal of the original vegetation cover, but this was a recent event, and possibly with little influence on the architecture of the ecological networks studied (Vacher et al. 2008). The evolutive history of the species that make up the networks, as metabolic and feeding characteristics that contribute strongly to the networks' topology (Eklöf et al. 2012), could be more determinant to the interactions between parasitoid and host than recent alterations, like the removal of vegetation cover. Both the parasitoids and their hosts developed a range of evolutive strategies that guarantee the infection of the host by the parasitoid, and the permanence of the species in the host community (Polyglottus 2011).

Phylogeny supersedes the effects of habitat characteristics and historical contingencies and of biogeography in the interactions between parasitoids and hosts (Mouillot et al. 2008b). Because these interactions emerged at the beginning of species diversification (Eklöf et al. 2012), the structure of these networks could be more related to the make-up of the communities than to habitat modification itself. Therefore, phylogenetic traits can prevail over ecological traits, e.g., host body size can determine parasite or parasitoid richness per host (Poulin et al. 2011). The abundance and the richness of hosts also seem to have an important effect on the abundance and richness of parasitoids (Ebeling et al. 2012). In fact, in this study, the more parasitized host species in adjacent matrices were those with the greater number of founded nests and with more brood cells provisioned (T. opacum, P. guadulpensis, and C. tarsata ). It seems that for this guild of wasps and bees, the host's abundance, rather than the size of their bodies, has an influence on the richness and abundance of their natural enemies. T. lactitarse, one of the largest wasps collected in this study (Buschini and Wolff 2006; Buschini et al. 2006), was less abundant and much less parasitized than T. opacum. Therefore, in adjacent matrices, T. opacum, $P$. guadulpensis, and C. tarsata might act as an abundant source of the Caenochrysis parvula, Caenochrysis intrincans, and Coelioxys cyrtocoelyoxis, respectively.

What we also perceive of food webs in both forest fragments and adjacent matrices is that the hosts have more partners than their natural enemies, and although in the adjacent matrices the rate of parasitism was higher than in forest fragments, there was no higher rate of natural enemies to host in these areas. Most species of natural enemies parasitized only one species of host, even Anthrax, which is a generalist species (Araujo et al. 2018; Lima et al. 2018), parasitized only the nests of $C$. tarsata. Wasps of the Chrysididae family were recorded as the most frequent parasitoids in Trypoxylon nests (Buschini and Wolff 2006; Buschini et al. 2006; 
Table II. The species dominance (DO) and frequency of occurrence (FO) of the bee and wasp species in adjacent matrices and forest fragments

\begin{tabular}{|c|c|c|c|c|c|c|c|c|}
\hline \multirow[b]{2}{*}{ Species } & \multirow[b]{2}{*}{$\begin{array}{l}\text { Number } \\
\text { of nests }\end{array}$} & \multicolumn{3}{|c|}{ Adjacent matrices } & \multirow[b]{2}{*}{$\begin{array}{l}\text { Number } \\
\text { of nests }\end{array}$} & \multicolumn{3}{|c|}{ Forest fragments } \\
\hline & & DO & FO & & & DO & FO & \\
\hline \multicolumn{9}{|l|}{ Crabronidae } \\
\hline $\begin{array}{l}\text { Trypoxylon agamemnon } \\
\text { (Richards) }\end{array}$ & 03 & 1.01 & 15 & Rare & 52 & 20.31 & 70 & Common \\
\hline $\begin{array}{l}\text { Trypoxylon opacum } \\
\text { (Brèthes) }\end{array}$ & 111 & 37.5 & 70 & Common & - & - & - & - \\
\hline $\begin{array}{l}\text { Trypoxylon lactitarse } \\
\text { (Saussure) }\end{array}$ & 22 & 7.43 & 50 & Common & 27 & 10.55 & 35 & Intermediary \\
\hline Pisoxylon sp. & - & - & - & - & 01 & 0.39 & 5 & Rare \\
\hline \multicolumn{9}{|l|}{ Vespidae } \\
\hline $\begin{array}{l}\text { Ancistrocerus } \\
\text { flavomarginatus (Brèthes) }\end{array}$ & - & - & - & - & 139 & 54.30 & 65 & Common \\
\hline $\begin{array}{l}\text { Monobia angulosa } \\
\text { (Saussure) }\end{array}$ & 01 & 0.34 & 5 & Rare & - & - & - & - \\
\hline $\begin{array}{l}\text { Pachodynerus grandis } \\
\text { (Willink \& Roig-Alsina) }\end{array}$ & 11 & 3.72 & 25 & Intermediary & - & - & - & - \\
\hline $\begin{array}{l}\text { Pachodynerus guadulpensis } \\
\text { (Bohart \& Stange) }\end{array}$ & 26 & 8.78 & 25 & Intermediary & - & - & - & - \\
\hline $\begin{array}{l}\text { Pachodynerus nasidens } \\
\text { (Latreille) }\end{array}$ & 32 & 10.81 & 30 & Intermediary & - & - & - & - \\
\hline $\begin{array}{l}\text { Zethus plaumanni } \\
\text { (Bohart \& Stange) }\end{array}$ & - & - & - & - & 03 & 1.17 & 10 & Rare \\
\hline \multicolumn{9}{|l|}{ Pompilidae } \\
\hline Auplopus rufipes (Banks) & 09 & 3.04 & 30 & Intermediary & 21 & 8.20 & 30 & Intermediary \\
\hline \multicolumn{9}{|l|}{ Sphecidae } \\
\hline Podium rufipes (Fabricius) & 12 & 4.05 & 30 & Intermediary & - & - & - & - \\
\hline Podium angustifrons (Kohl) & - & - & - & - & 03 & 0.78 & 5 & Rare \\
\hline \multicolumn{9}{|l|}{ Apidae } \\
\hline $\begin{array}{l}\text { Tetrapedia diversipes } \\
\text { (Klug) }\end{array}$ & 02 & 0.68 & 5 & Rare & - & - & - & - \\
\hline Centris tarsata (Smith) & 65 & 21.96 & 65 & Common & - & - & - & - \\
\hline \multicolumn{9}{|l|}{ Megachilidae } \\
\hline Megachile sp. & - & - & - & - & 11 & 4.30 & 30 & Intermediary \\
\hline $\begin{array}{l}\text { Megachile benigna } \\
\text { (Mitchell) }\end{array}$ & 02 & 0.68 & 10 & Rare & - & - & - & - \\
\hline
\end{tabular}

Buschini and Fajardo 2010), and there was specificity in their interactions, the same occurring between the species of Coelioxys, C. tarsata, and Megachile (Moureapis) sp.

Parasitoid and insects species richness, in general, has been found to be positively correlated with vegetation diversity and plant architectural complexity (Stinson and Brown 1983; Hawkins and Lawton 1987) which may then spill over to adjacent habitats (Tscharntke et al. 2005), although in this study, and in those also carried out in the state of Paraná, southern Brazil (Iantas et al. 2017), the greatest richness and abundance of wasps and bees and their 
Table III. Names of natural enemy species and their host (wasps and bees), the guild of the host ( $W$ : wasp; $B:$ bee), and numbers of parasitized cells

\begin{tabular}{|c|c|c|c|}
\hline Natural enemy species & Host species & Guild & Parasitized brood cells \\
\hline \multicolumn{4}{|l|}{ Hymenoptera: Chrysididae } \\
\hline 01-Caenochrysis armata & 23-Auplopos rufipes & $\mathrm{W}$ & 2 \\
\hline 02-Caenochrysis intrincans & 24-Pachodynerus guadulpensis & $\mathrm{W}$ & 16 \\
\hline 03-Caenochrysis parvula & 25-Trypoxylon opacum & $\mathrm{W}$ & 21 \\
\hline 04 Caenochrysis nigropolita & 25-Trypoxylon opacum & $\mathrm{W}$ & 3 \\
\hline 05-Chrysis intricans & 24-Pachodynerus guadulpensis & $\mathrm{W}$ & 1 \\
\hline 06-Ipsiura myops & 26-Ancistrocerus flavomarginatus & W & 5 \\
\hline 07_Ipsiura cooperi & 26-Ancistrocerus flavomarginatus & $\mathrm{W}$ & 3 \\
\hline 08-Neochrysis catarinensis & 27-Trypoxylon agamemnon & $\mathrm{W}$ & 7 \\
\hline 09-Pleurochrysis postica & 26-Ancistrocerus flavomarginatus & W & 1 \\
\hline \multicolumn{4}{|l|}{ Ichneumonidae: } \\
\hline 10-Campopleginae sp. & 32-Megachile sp. & $\mathrm{B}$ & 1 \\
\hline 11—Polysphincta sp. & 25-Trypoxylon opacum & $\mathrm{W}$ & 1 \\
\hline \multirow[t]{2}{*}{ 12-Photocryptus sp. 1} & 23-Auplopus rufipes & W & 1 \\
\hline & 27-Trypoxylon agamemnon & W & 1 \\
\hline 13-Photocryptus sp. 2 & 28-Trypoxylon lactitarse & W & 1 \\
\hline 14 Photocryptus sp. 3 & 23-Auplopus rufipes & W & 1 \\
\hline 15-Photocryptus sp. 4 & 23-Auplopus rufipes & W & 3 \\
\hline \multicolumn{4}{|l|}{ Tachinidae: } \\
\hline \multirow[t]{2}{*}{ 16-Eucelatoria sp. } & 24 -Pachodynerus guadulpensis & $\mathrm{W}$ & 2 \\
\hline & 25-Trypoxilon opacum & W & 1 \\
\hline \multicolumn{4}{|l|}{ Sarcophagidae: } \\
\hline 17-Amobia floridensis & 29_Pachodynerus nasidens & $\mathrm{W}$ & 2 \\
\hline \multicolumn{4}{|l|}{ Bombyliidae: } \\
\hline 18-Anthrax sp. & $30-$ Centris tarsata & $\mathrm{B}$ & 2 \\
\hline \multicolumn{4}{|l|}{ Mutillidae: } \\
\hline 19-Sphaeropthalma sp. & $30-$ Centris tarsata & $\mathrm{B}$ & 1 \\
\hline \multicolumn{4}{|l|}{ Apidae: } \\
\hline 20 -Mesocheira bicolor & $30-$ Centris tarsata & $\mathrm{B}$ & 1 \\
\hline 21-Coelioxys sp. & $30-$ Centris tarsata & $\mathrm{B}$ & 12 \\
\hline 22-Coelioxys tolteca & 31-Megachile sp. & $\mathrm{B}$ & 2 \\
\hline
\end{tabular}

parasitoids have been found always in the matrices where the forest was totally removed, and which are the environments with less structural complexity. We need to be very careful in interpreting these results because it is quite possible that trap nests in these areas had higher colonization rates because there are few other nesting opportunities available due to the lack of trees, and thus, the artificial nests become highly attractive for cavity-nesting bees and wasps. Conversely, in forests, there may be many natural holes in the trees, with different diameters and lengths, and thus, the trap nests may be encountered and colonized at a much lower rate. Buschini and Wolff (2006) had already suspected of this possibility because by installing only trap-nests with $1.0 \mathrm{~cm}$ diameter in deforested areas, T. opacum was the species 
Table IV. Qualitative and quantitative mean value measures of networks in forest fragments and adjacent matrices and the $p$ value of Student's $t$ test between areas

\begin{tabular}{lccc}
\hline Qualitative measures & Adjacent matrices & Forest fragments & $p$ value \\
\hline Specialization & 1 & 1 & \\
Connectance & 0.30 & 0.34 & 0.47 \\
Robustness & 0.55 & 0.49 & 0.30 \\
Evenness of links & 0.43 & 045 & 0.85 \\
Generalism & 1 & 1 & \\
Vulnerability & 1.77 & 1.65 & 0.65 \\
Density of links & 1.38 & 1.31 & 0.66 \\
Parasitism rates & 0.08 & 0.06 & 0.47 \\
\hline
\end{tabular}

that most nestled in these traps, and when they also installed the trap nests with $0.7 \mathrm{~cm}$, these wasps began to nest only in these traps with a smaller diameter. It would be of great interest to count the number of holes in the forest, which would give us a better idea of the availability of this resource in these areas. Future studies focusing on the ecology of this species, combining both natural and artificial holes (trap nests), will certainly allow a better understanding
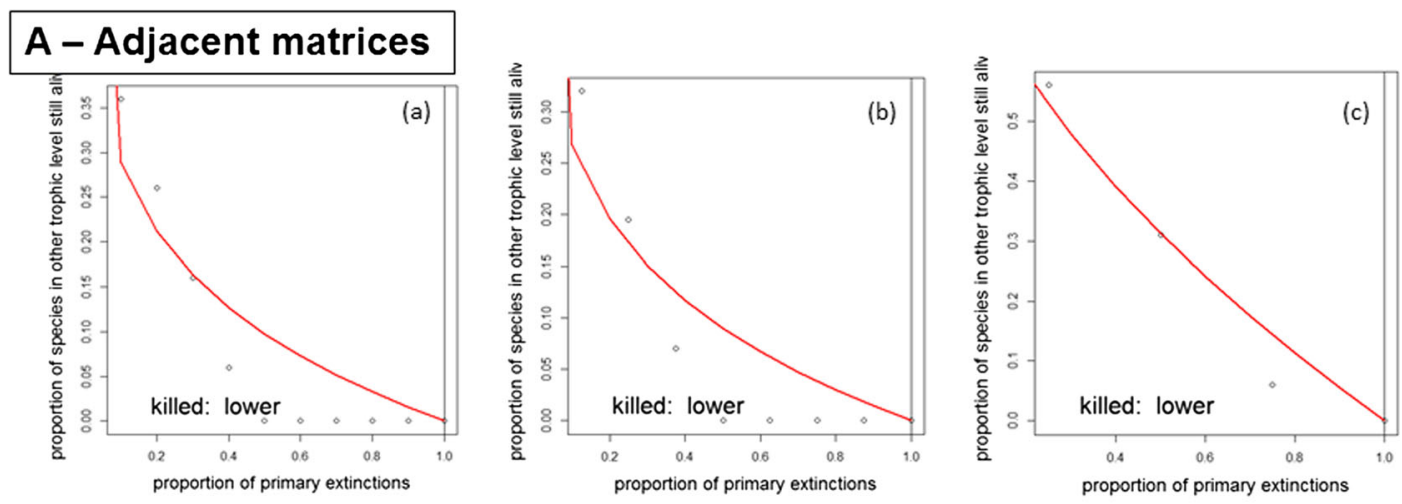

\section{B - Forest fragments}
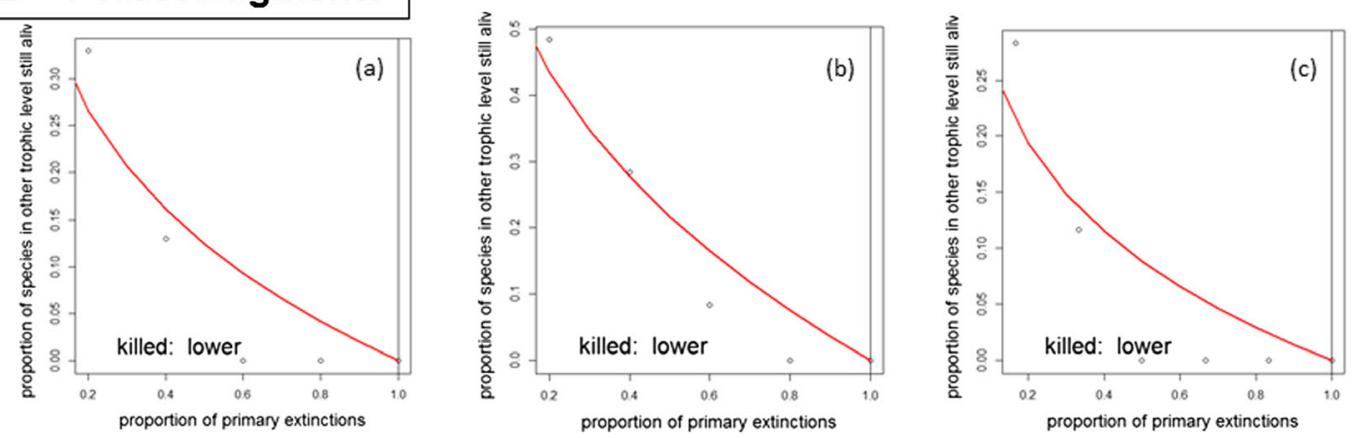

Figure 2 Secondary extinction curve: extinction of parasitoids as a function of the extinction of their hosts in forest fragments (A) and in adjacent matrices (B ): (a) is Turvo; (b) is Palmerinha; (c) is Guarapuava. 


\section{A - Adjacent matrices}

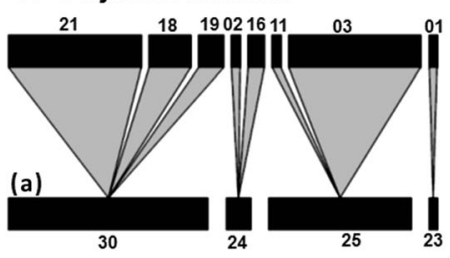

\section{B - Forest fragments}

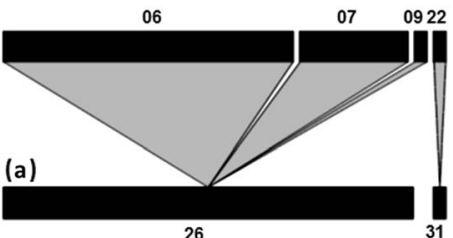

(b)
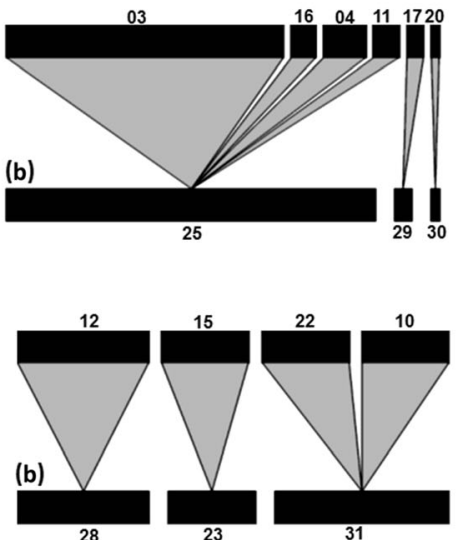

(c)
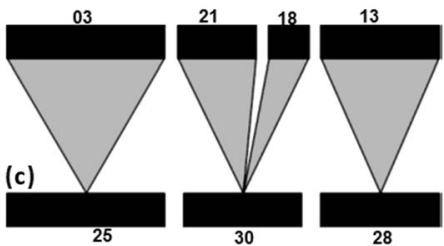

28

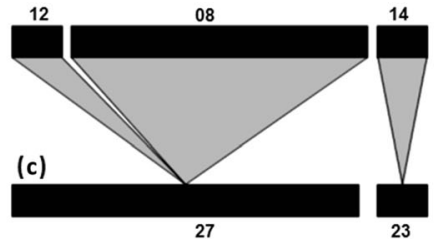

Figure 3 Eulerian graphs representing the interaction networks between parasitoids (higher trophic level), bees and wasps (lower trophic level) in forest fragments (A) and in adjacent matrices (B ): (a) is Turvo; (b) is Palmerinha; (c) is Guarapuava. The width of the lines in the weighted matrix indicates total interaction frequency between one pair of species (names of species: see Table III).

about the preference of these insects for the types of cavities in the different habitats.

We thereby conclude that habitat simplification, due to anthropic action, causes a substitution of wasp and bee species, and mainly of their natural enemies that are typical of Mixed Ombrophilous Forest, one of the plant physiognomies of the Atlantic Forest. Although the structure of their food web has not been altered, the human action caused a substitution in the composition of the species on more than one trophic level and probably promoted the cascade replacement of the species throughout this ecosystem.

\section{ACKNOWLEDGEMENTS}

We thank CAPES (Coordenação de Aperfeiçoamento de Pessoal de Nível Superior) for the scholarship and the Graduate Program in Evolutionary Biology of Universidade Estadualdo Centro-Oeste (UNICENTRO), Paraná state, Brazil. We also thank Dr. Bolívar Rafael Garcete Barrett of the Museu Nacional de Historia Natural do Paraguay for the identification of Eumeninae, Dr. Gabriel Augusto R. Melo of UFPR (Paraná state, Brazil) for bee identification, Dr. Eduardo Fernando dos Santos for the identification of Pompilidae, and Dra Angélica Maria Penteado Martins Dias of UFSCAR (São Paulo state, Brazil) for identifying the Ichneumonidae.

\section{AUTHOR CONTRIBUTIONS}

Michele Cristina Nether carried out field research, drafted the manuscript, and performed the analyses. This manuscript is part of the results of JI master's thesis. Jessica Dudek helped collect field data and made corrections in the manuscript. Maria LuisaTunes Buschini was responsible for the direction and correction of the manuscript. All authors read and approved the final manuscript.

\section{COMPLIANCE WITH ETHICAL STANDARDS}

Conflict of interest The authors declare that they have no conflict of interest.

Interaction trophique et diversité d'abeilles et de guêpes (Hymenoptera: Aculeata) qui nichent dans les cavités dans les fragments de forêt de l'Atlantique et dans les zones adjacentes

Assemblage / biodiversité / réseau alimentaire / insectes / réseau / nids-pièges

Trophische Wechselwirkungen und Diversität von in Höhlen nistenden Bienen und Wespen (Hymenoptera: Aculeata) in Restflächen des atlantischen Regenwaldes und in angrenzenden Flächen 


\section{Gruppierung / Biodiversität / Nahrungsnetz / Insekten / Netzwerk / Trapnester}

Publisher's note Springer Nature remains neutral with regard to jurisdictional claims in published maps and institutional affiliations.

\section{REFERENCES}

Almeida-Neto, M., Guimarães, P., Guimarães, P.R., Loyola, R.D. \& Ulrich, W. (2008) A consistent metric for nestedness analysis in ecological systems: reconciling concept and measurement. Oikos, 117 : 1227-1239.

Araujo, G.J., Fagundes, R., Antonini, Y. (2018) Trapnesting hymenoptera and their network with parasites in recovered Riparian forests Brazil. Neotrop. Entomol., 1-11.

Bascompte, J., Melián, C.J., Sala, E. (2005) Interaction strength combinations and the overfishing of a marine food web. Proc. Natl. Acad. Sci. U. S. A. 102, 54435447.

Bascompte, J., Jordano, P., Olesen, J.M. (2006) Asymmetric Coevolutionary Networks Facilitate Biodiversity Maintenance. Science 312, 431-433.

Bersier, L.F., Banasek-Richter, C., Cattin, M.F. (2002) Quantitative descriptors of foodweb matrices. Ecology 83, 2394-2407.

Blüthgen, N., Menzel, F., Blüthgen N. (2006). Measuring specialization in species interaction networks. Ecology 6, 1-12.

Blüthgen, N.; Fründ, J.; Vázquez, D.; Menzel, F. (2008) What do interaction network metrics tell us about specialization and biological traits? Ecology 89, 3387-3399

Burgos, E., Ceva, H., Perazzo, R.P., Devoto, M., Medan, D., Zimmermann, M., Maríadelbue, A. (2007) Why nestedness in mutualistic networks? J. Theor. Biol. 249, 307-313.

Buschini, M.L.T. (2006) Species diversity and community structure in trap-nesting bees in Southern Brazil. Apidologie 37, 58-66.

Buschini, Maria Luisa Tunes; Fajardo, Saul. (2010) Biology of the solitary wasp Trypoxylon (Trypargilum) agamemnon Richards 1934 (Hymenoptera: Crabronidae) in trap-nests. Acta Zool., 91 (4), 426432.

Buschini, M.L.T., Woiski, T.D. (2008) Alpha-beta diversity in trap nesting wasps (Hymenoptera: Aculeata) in Southern Brazil. Acta Zool. (Stockholm) 89, 351-358.

Buschini, M. L. T., \& Wolff, L. L. (2006). Notes on the biology of Trypoxylon (Trypargilum) opacum Brèthes (Hymenoptera; Crabronidae) in southern Brazil. Braz. J. Biol., 66 (3), 907-917.

Buschini, M. L. T.; Niesing, F.; Wolff, L. L. (2006) Nesting biology of Trypoxylon (Trypargilum) lactitarse
Saussure (Hymenoptera, Crabronidae) in trap-nests in southern Brazil. Braz. J. Biol., 66 (3), 919-929.

Chao, A. (1987) Estimating the population size for capturerecapture data with unequal catchability. Biometrics 43, 783-791.

Colwell, R. K., Mao, C. X., Chang, J. (2004) Interpolating, extrapolating, and comparing incidence-based species accumulation curves. Ecology 85, 2717-2727.

Conservation International (2017) [online] URL http://www.conservation.org/How/Pages/Hotspots. aspx (accessed on November 2017)

Dormann, C.F., Gruber, B., Fründ, J. (2008) Introducing the bipartite package: analysing ecological networks. interaction, 1, 0-2413793

Ebeling, A.; Klein, A.M.; Weisser, W.W., Tscharntke, T. (2012) Multitrophic effects of experimental changes in plant diversity on cavity-nesting bees, wasps, and their parasitoids. Oecologia 169, 453-65.

Eklöf, A., Helmus, M.R., Moore, M., Allesina, S. (2012) Relevance of evolutionary history for food web structure. Proc. R. Soc. Lond. B Biol. Sci. 279, 1588-1596.

Flores, L.M.A.; Zanette, L.R.S., Araujo, F.S. (2018) Effects of habitat simplification on assemblages of cavity nesting bees and wasps in a semiarid neotropical conservation área. Biodivers. Conserv. 27, 311-328.

Godfray, H.C.J., Lewis, O.T., Memmott, J. (1999) Studying insect diversity in the tropics. Philos. Trans. R. Soc. Lond. B 354, 1811-1824.

Hawkins, B.A., Lawton, J.H. (1987) Species richness for parasitoids of British phytophagous insects. Nature 326, 788-790.

Hillebrand, H., Matthiessen, B. (2009) Biodiversity in a complex world: consolidation and progress in functional biodiversity research. Ecol. Lett. 12, 14051419.

Hooper, D.U., Chapin, F.S., Ewel, J.J., Hector, A., Inchausti, P., Lavorel, S., Lawton, J.H., Lodge, D.M., Loreau, M., Naeem, S., Schmid, B., Setálá, H., Symstad, A.J., Vandermeer, J., Wardle, D.A. (2005) Effects of biodiversity on ecosystem functioning: a consensus of current knowledge. Ecol. Monogr. 75, 3-35.

Iantas, J., Woitowicz, F.C.G., Buschini, M.L.T. (2017) Habitat modification and alpha-beta diversity in trapnesting bees and wasps (Hymenoptera: Aculeata) in southern Brazil. Trop. Zool. 30, 83-96.

IAPAR - Instituto Agronômico do Paraná (2013) Histórico da Estação Agrometeorológica de Guarapuava. IAPAR, Londrina. [online] http://www.iapar.br. (accessed on December 2013)

Ings, T.C., Montoya, J.M., Bascompte, J., Blüthgen, N., Brown, L., Dormann, C.F. et al. (2009). Ecological networks beyond food webs. J. Animal Ecology 78, 253-269.

Klein, A., Steffan-Dewenter, I., Tscharntke, T. (2006). Rain forest promotes trophic interactions and diversity of trap-nesting Hymenoptera in adjacent agroforestry. J. Anim. Ecol. 75, 315-323. 
Lawton, J.H. (1983) Plant architecture and the diversity of phytophagous insects. Annu. Rev. Entomol. 28, 23-39.

Lima, R., Oliveira, D. M., \& Garófalo, C. A. (2018). Interaction Network and Niche Analysis of Natural Enemy Communities and their Host Bees (Hymenoptera: Apoidea) in fragments of Cerrado and Atlantic Forest. Sociobiology, 65 (4), 591-602.

Luck, G.W., Daily, G.C., Ehrlich, P.R. (2003) Population diversity and ecosystem services. Trends Ecol. Evol. 18, 331-336.

Ludwig, J.A., Reynolds, J.F. (1988) Statistical ecology: a primer in methods and computing. Wiley, New York.

Macarthur, R.H., Macarthur, J.W. (1961) On bird species diversity. Ecology 42, 594-598.

Memmott, J., Waser, N.M., Price, M.V. (2004) Tolerance of pollination networks to species extinctions. Proc. R. Soc. Lond. B Biol. Sci. 271, 2605-2611.

Montoya, J.M., Stuart, L.P., Solé, R.V. (2006) Ecological networks and their fragility. Nature 442, 259-264.

Morris, R.J., Gripenberg, S., Lewis, O.T., Roslin, T. (2014) Antagonistic interaction networks are structured independently of latitude and host guild. Ecol. Lett. 17, 340-349.

Mouillot, D., Krasnov, B.R., Shenbrot, G., Poulin, R. (2008a) Connectance and parasite diet breadth in flea-mammal webs. Ecography 31, 16-20.

Mouillot, D., Krasnov, B.R., Poulin, R. (2008b) High intervality explained by phylogenetic constraints in host-parasite webs. Ecology 89, 2043-2051.

Newman, M.E.J. \& Girvan, M. (2004) Finding and evaluating community structure in networks. Phys. Rev. E, 69, 026113.

Oksanen, J., Blanchet, F. G., Kindt, R., Legendre, P., Minchin, P. R., O’hara, R. B., ... Oksanen, M. J. (2013) Package 'vegan'. Community ecology package, version, 2(9)

Palma, S. (1975) Contribución al studio de los sifonoforos encontrados frente a la costa de Valparaiso. Aspectos ecológicos. II Simpósio Latino Americano Sobre Oceanografia Biológica, Dóriente, Venezuela.

Palmer, M.W. (1991) Estimating Species Richness: The Second-Order Jackknife Reconsidered. Ecology 72, 1512-1513.

Polyglottus, M. (2011) Mockingbird Tales: Readings in Animal Behavior. [onine] URL http://cnx. org/content/coll1211/1.5/. (accessed on September 2017)

Poulin, R., Guilhaumon, F., Randhawa, H.S., Luque, J.L., Mouillot, D. (2011) Identifying hotspots of parasite diversity from species-area relationships: host phylogeny versus host ecology. Oikos 120, 740-747.
Ricketts, T.H. (2004) Tropical forest fragments enhance pollinator activity in nearby coffee crops. Conserv. Biol. 18, 1262-1271.

Schüepp, C., Herrmann, J.D., Herzog, F., Schmidt-Entling, M.H. (2011) Differential effects of habitat isolation and landscape composition on wasps, bees, and their enemies. Oecologia 165, 713-721.

Smith, E. P., Van Belle, G. (1984) Nonparametric estimation of species richness. Biometrics 40, 119-129.

Smith, M.D., Knapp, A.K., Collins, S.L. (2009) A framework for assessing ecosystem dynamics in response to chronic resource alterations induced by global change. Ecology 90, 3279-3289.

Steffan-Dewenter, I. (2002) Land scape context affects trap-nesting bees, wasps, and their natural enemies. Ecol. Entomol. 27, 631-637.

Steffan-Dewenter, I. (2003) Importance of Habitat Area and Landscape Context for Species Richness of Bees and Wasps in Fragmented Orchard Meadows. Conserv. Biol. 17, 1036-1044.

Stein, A., Gerstner, K., Kreft, H. (2014) Environmental heterogeneity as a universal driver of species richness across taxa, biomes and spatial scales. Ecol. Lett. 17, $866-880$.

Stinson, C.S.A., Brown, V.K. (1983) Seasonal changes in the architecture of natural plant communities and its relevance to insect herbivores. Oecologia 56, 67-69.

Tscharntke, T., Rand, T.A., Bianchi, F.J.J.A. (2005) The landscape context of trophic interactions: insect spillover across the crop-non-crop interface. Ann. Zool. Fenn. 42, 421-432.

Tylianakis, J.M., Klein, A.M., Lozada, T., Tscharntke, T. (2006) Spatial scale of observation affects $\alpha, \beta$ and $\gamma$ diversity of cavity-nesting bees and wasps across a tropical land-use gradient. J. Biogeogr. 33 , 12951304.

Tylianakis, J.M., Tscharntke, T., Lewis, O.T. (2007) Habitat modification alters the structure of tropical hostparasitoid food webs. Nature 445, 202-205.

Tylianakis, J.M., Lalibert, E., Nielsen, A., Bascompte, J. (2010) Conservation of species interaction networks. Biol. Conserv. 143, 2270.

Vacher, C., Piou, D., \& Desprez-Loustau, M. L. (2008). Architecture of an antagonistic tree/fungus network: the asymmetric influence of past evolutionary history. PLoS One, 3 (3), e1740.

Wilby, A., Orwin, K.H. (2013) Herbivore species richness, composition and community structure mediate predator richness effects and top-down control of herbivore biomass. Oecologia 172, 1167-1177. 